\title{
Effects of Soil and Water Conservation Structures on Crop Yield, Lemo District, Southern Ethiopia
}

\author{
Yohannes Horamo More ${ }^{*}$, Mulatu Chernet Madolo \\ Department of Natural Resources Management, Wachemo University, Ethiopia.
}

How to cite this paper: Yohannes Horamo More, Mulatu Chernet Madolo. (2020) Effects of Soil and Water Conservation Structures on Crop Yield, Lemo District, Southern Ethiopia. International Journal of the Science of Food and Agriculture, 4(4), 519-527.

DOI: 10.26855/ijfsa.2020.12.021

Received: November 21, 2020

Accepted: December 25, 2020

Published: January 5, 2021

*Corresponding author: Yohannes Horamo More, Department of Natural Resources Management, Wachemo University, Ethiopia.

Email: yohannesh2005@gmail.com

\begin{abstract}
The soil loss in Ethiopia in general and in southern Ethiopia in particular has becoming critical to be considered as burning issue. This research was carried out to investigate the effects of soil bund and fanyajuu bund on crop yield on the cropping pattern of the farmers on their fields. Randomized complete block design (RBCD) with seven replication and three position, (lower, middle and upper) and wheat as a test crop were used for the investigation. Data on plant height, 1,000 seed weight, number of seed per spike, grain yield and day to $50 \%$ spiking were taken. Considering the seven locations level fanyajuu and level bund treated plots showed $50.9 \%$ and $43.2 \%$ greater yield than the control plot, respectively. Correlation analysis showed significant correlation with most of soil physico-chemical properties and agronomic characteristics on level bund and level fanyajuu whereas it showed insignificant correlation with control plot. Finally it was suggested that further study should be conducted under different agro-ecological zones to attain more comprehensive results.
\end{abstract}

\section{Keywords}

Soil bund, fanyajuu, crop yield, wheat

\section{Introduction}

Recent estimate indicate annual soil loss in Ethiopia is between 1.5 and 3 billion tons [1] of this about $50 \%$ occurs in cropland where soil loss has been reported to be very high (296 tons/ha/year) on a 16\% slope with teff crop (Eragrostisabasinica) on nitisols [2-3]. The Ethiopian High Land Reclamation Study (EHRS) estimated that about 50\% of the high lands are already significantly eroded of which about 14 million hectares are severely eroded. In Ethiopia, two millions hectares have reached a stage of irreversible destruction and cannot sustain cropping in the future [4].

The effects of soil degradation can be described as: Flood hazard, decreases in productivity of the land as well as production per unit area and the regulatory capacity of the mountains is drastically reduced and the overall effect is frequent drought, famine, and related disasters [5,6]. Ethiopia has a long history of following traditional conservation methods. These are numerous examples of certain parts of the country where these techniques can be seen. For example, stone terracing in konso, Gomugoffa, random bench terraces in North Shoa and Hararge, contour bench terraces and tied ridges in Konso, drainage furrows of North-East Shoa, and sod rotation, trash bunds, trash heap composting and fallowing. To date, these techniques have not been evaluated nor has there been any attempt to improve them or popularize them $[7,8]$.

The scientific conservation programme is a recent phenomenon. A start was made in early 1970s. But serious attempts on a large scale were delayed until the early 1970s, when assistance of the WFP and UNDP/FAO become available. The Ethiopian high lands saw probably the most extensive soil conservation activity in 1970s and 1980s [9]. Between 1980 and 1990, about 2.3 million ha of land was covered by hill side terraces for a forestation of steep slope; about 1 million hectare was planted with different tree seedlings [10,11].

One of these high land areas of Ethiopia is Hadiya zone Lemmo district where these soil conservation practices by 
government programme is carried out. According to development of agricultural and natural resource department [12] of Hadiya zone 21,185.89 hectare was covered by tree seedlings between 2002 and 2005, and 2006 to 2012, 15,000 ha were covered by soil conservation structures. Even if so much amount of land is covered by tree seedlings and soil conservation structures their awareness by the farmers was low and the effects brought by sustainable soil and fanyajuu bund are not yet investigated. Hence this research concentrated to evaluate the effectiveness of soil and fanyajuu bund on wheat crop yield in comparison with unprotected land, where no soil and water conservation measures are taken.

\section{Materials and Methods}

\subsection{Description of the Study Area}

This study was conducted in Lemo District, Hadiya zone, Southern Ethiopia. Geographically the study area is located in $07^{\circ} 41^{\prime} \mathrm{N}$ Latitude and $037^{\circ} 31^{\prime} \mathrm{E}$ Longitude. Topography of the study area is rugged high land and hilly areas with range of slope from $2 \%$ to $35 \%$. Generally, the terrain is mountainous, undulating and broken type that is very much prone to soil erosion. As stated by [13], land-use planning the soil types or the distribution of soil units in study area is sand sandy loam, loam and clay. As it has been indicated above, the most widely distributed or that covers large area is loam. They are distinguished by high amount of clay and these soils are high fertile and probably well-drained.

The District is found in "Woina Dega" agro-climatic zone with altitudinal range of 1,950-2,400 meter above sea level. It has a temperature range of $15-18^{0} \mathrm{C}$ and an average rainfall is $1,150 \mathrm{~mm}$. In the study area, there are a number of rivers and seasonal streams that drain to the area. They supply water for both drinking and sanitation purposes. The interventions of human being have influenced the natural vegetation in the study area greatly. Farmers are already adapted to planting of some tree species in the District, to meet the demands for wood need. This is actually dominated by different types of Eucalyptus species [12].

The District has a population of 207,469, of which 103,576 are male and 103,893 female. The dominant land-use types in the District are sedentary mixed farming, whereby the cultivated land accounts for $89 \%$ of the total land area. This in turn indicates that there is great pressure on land. The area practices complete integration of trees, crop and animal production that is similar to [14].
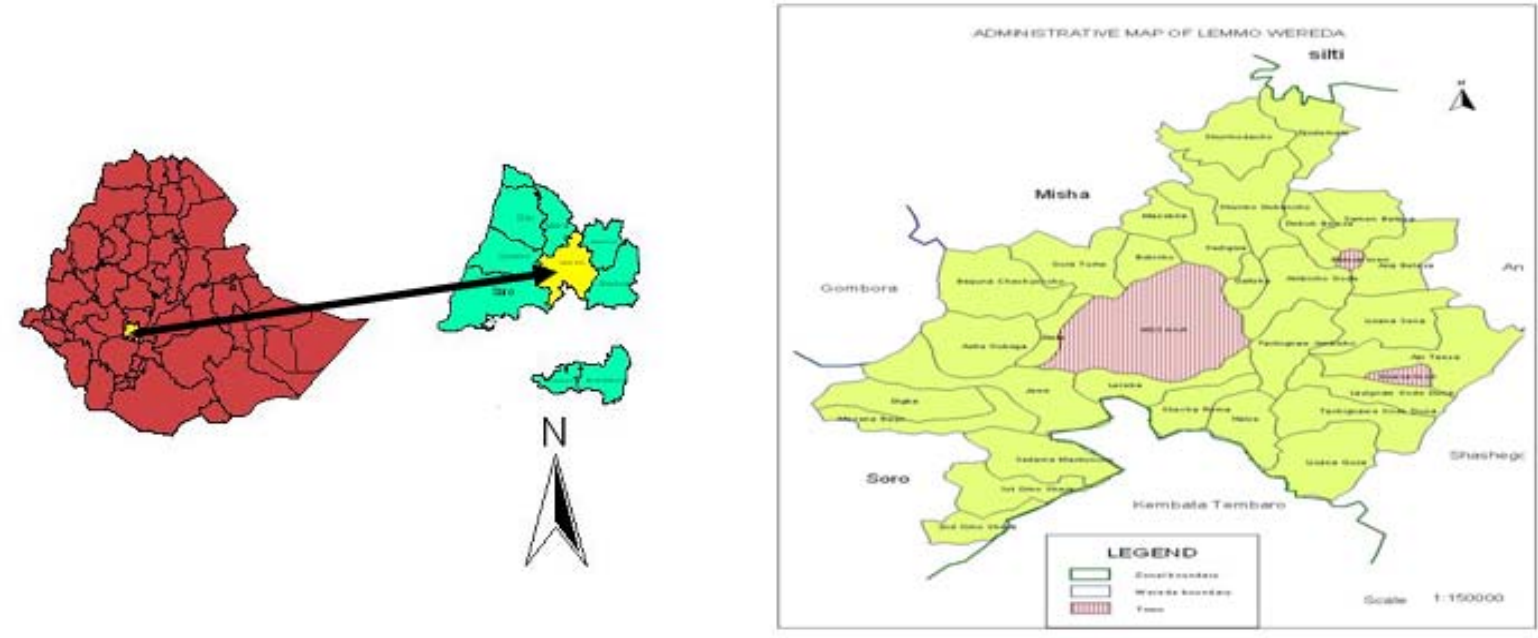

Figure 1. Location of Lemo District in Hadiya zone, Ethiopia (Source: Survey result).

\subsection{Field Experiment and Data Collection}

\subsubsection{Research Experimental Design}

The type of the study governs the choice of the study design. In this study, the pragmatic (matter of-factual) world outlook or rational approach was suitable since it is factual-world practice-oriented and problem-centered [15]. In this study, a mixed methods design that is, a mix of quantitative and qualitative approach were employed for collection of data and data analysis. This study adopted the pragmatism philosophic approach [16]. The experiment was done on farmer's field using level bund, level fanyajuu and control plot as treatment and wheat as a test crop. Neither farm yard manure nor mineral fertilizer was applied in all the treatments during experimentation. The experiment was laid out in randomized complete block design (RCBD) with 63 observations per variable that is 7 replication, 3 treatments, 3 positions and plot size of $378 \mathrm{~m}^{2}$. 
Plot Layout

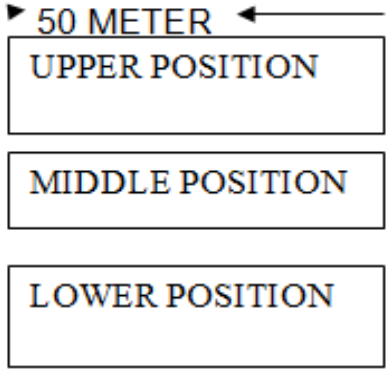

LEVEL BUND

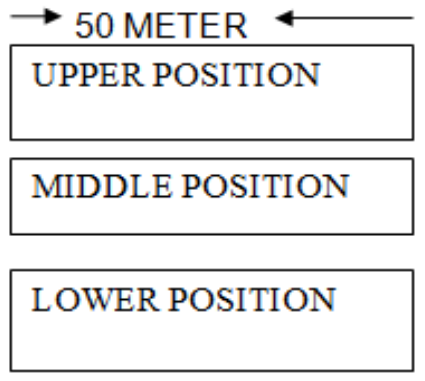

CONTROL

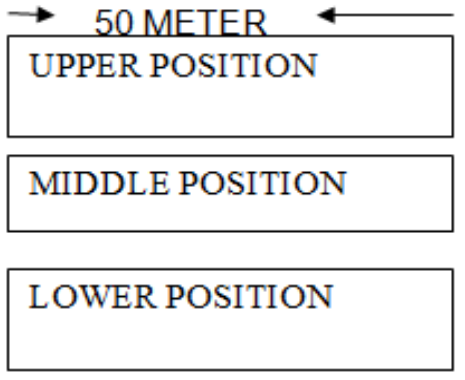

LEVEL FANYAJUU

Figure 2. Experimental Layout of Plots.

Throughout the crop season, all the experimental plots were observed closely and seen that there was no serious disease and pest incidence noticed on the plant and not considered to be a factor in affecting growth or yield of crop. When the crop in the experiment plot was ready for harvest it was harvested and collected from each of the plot separately using a new sack. After threshing the grain from each plot were weighed and the value was extrapolated for the total crop yield per hectare basis. Days to 50\% spiking and plant height were recorded on the same day when $50 \%$ of the plant in the plot reaches the respective phonological stage. Plant height of wheat crop was measured in $\mathrm{cm}$ from the three position one farmer plot 72 plants which are randomly taken from each plot 10 days before harvesting. At harvest time spikes were taken manually and thousand grains were counted and weighed from the bulk of shelled grain at moisture content $12 \%$ level and expressed in grams. Seed moisture was determined in [17]seed quality testing by oven dry method rather than the quick method in order to avoid errors during reading of the meter which was less precise than the results determined with the air-oven method[18].In this method the wheat was grinded by grinding machine and after grinding a sample of $4 \mathrm{gm}$ was taken and put in the oven of $133^{\circ} \mathrm{c}$ for two hours after two hours it was taken from the oven and placed in the desiccators for cooling and after ten minutes it was measured to obtain the weight and calculate for the moisture.

\subsubsection{Data Collection}

For each experimental plot all parameters (grain yield kg/ha, days to 50\% spiking and maturity, plants height in (cm) and thousand grain weight (kg) crop yield was collected using an appropriate sampling technique). When the crop in the experiment plot was ready for harvest, it was harvested and collected by sacks from each plot separately in order to avoid grain loss during threshing. The grain was weighed and recorded as grain yield in $\mathrm{kg}$ per hectare. Days to $50 \%$ spiking and maturity of wheat was recorded when fifty percent of the plant in a plot reach the respective phonological stage. Plant height of wheat is measured in cm from twenty four plants from each position (upper, middle and lower) sampled randomly from left, right and center of each plot one week before harvesting. Thousand grain weights was measured after sampling from the bulk of shelled grain moisture content of $12 \%$ level for all samples and expressed in grams.

\subsection{Data Analysis}

The data collected for different parameters regarding crop yield were analyzed statistically using analysis of variance for 7 replication of RCBD was computed using the SAS to show if there was significant difference among the treatment means for the different parameters. Least significance difference was used to separate means from each other among the locations using $5 \%$ probability level. Pearson correlation coefficient was used to show the relationship and significance of the recorded wheat yield.

\section{Results and Discussion}

\subsection{Impacts of Soil and Water Conservation Structures on Wheat Yield}

The second main objective of this paper was to investigate the effects of conservation structures on wheat crop yield and yield components. From each treated conservation structure and untreated plots, plant height in centimeter (cm), number of seed per spike, 1,000 seed weight in gram (gm), day to $50 \%$ spiking and grain yield in quintal per hectare were recorded during the growth period and harvest time from plant samples taken from the plots. The data on wheat yield and agronomic characteristics as affected by different soil and water conservation treatment at seven locations is shown in (Table 1). The soil and water conservation structures displayed a statistically significant effect $(\mathrm{P} \leq 0.05)$ on 
wheat plant height, number of seed per spike, days to 50\% spiking and grain yield.

In order to display the different effects of the soil and water conservation structures on agronomic characteristics and yield a comparison of the averages of the seven locations were made on wheat crop. The relative average mean of 9.04 quintalt/hectare (55\%) was recorded on level fanyajuu and 7.64 quintal/hectare (45\%) increment were recorded on level bund and the highest mean yield increments due to conservation structures was recorded on Ambicho-six with level bund (13.94 quintal/hectare), and Ana Ballesa three level fanyajuu (13.5 quintal/hectare) over the control plots (Table 1). But in the overall mean increment the highest percent increment was recorded on level fanyajuu (Table 1). This high yield increment may be due to crop rotation and organic matter and nutrient availability on treated plots relative to the control plot. This finding was in agreement with [19] and [20] which showed that bean yield was increased because of fanyajuu, study by [21] also estimated that on the average field protected by bunds have higher sorghum yield than the control plot and [22] estimated yields of wheat and faba bean grown on soil accumulation and soil erosion segments of terraces and on un-terraced (upslope) areas in Degua Tembien (same plots as used by [23] yields were higher than non-terraced fields).

Table 1. Wheat yield versus treatments

\begin{tabular}{cccc}
\hline \multirow{2}{*}{ Locations/replications } & \multicolumn{3}{c}{ Yield increment in (\%) over the control plot } \\
\cline { 2 - 4 } & Control plot qt/ha & Level bund & Level fanyajuu \\
\hline North Ballesa sample one $\left(\mathrm{R}_{1}\right)$ & 14.71 & 4.74 & 10.08 \\
North Ballesa sample two $\left(\mathrm{R}_{2}\right)$ & 22.99 & 13.06 & 2.8 \\
Ana Ballesa sample three $\left(\mathrm{R}_{3}\right)$ & 20.14 & 4.67 & 13.5 \\
Ana Ballesa sample four $\left(\mathrm{R}_{4}\right)$ & 19.43 & 2.67 & 4.21 \\
Ana Ballesa sample five $\left(\mathrm{R}_{5}\right)$ & 15.86 & 8.43 & 13.9 .19 \\
Amibicho sample six $\left(\mathrm{R}_{6}\right)$ & 13.07 & 5.95 & 12.36 \\
Ambicho sample seven $\left(\mathrm{R}_{7}\right)$ & 17.15 & 7.64 & 10.17 \\
Mean & & & 9.04 \\
\hline
\end{tabular}

(Source: survey result)

The possible reason of yield decrease on the control plot is due to less amount of organic matter, nitrogen, phosphorous, organic carbon, which is decreased and washed away because of water erosion (Table 2 and Table 7). Similar to study of [24], founda yield increment of 7.43\% in fields treated with level bunds compared with untreated plot.

A significantly higher $(\mathrm{P} \leq 0.05)$ plant height, 1,000 seed weight of wheat, number of seed per spike was observed in both level bund and level fanyajuu compared to control plots (Table 2). Both level bund and level fanyajuu produced a significantly higher $(\mathrm{P} \leq 0.05)$ yield than the untreated plot. However, no significant differences $(\mathrm{P} \leq 0.05)$ were observed between level bund and level fanyajuu in terms of number of seeds per spike, grain yield and 1,000 seed weight. Considering the mean yield on the seven locations wheat produced under the influence of level bund was 26.39 quintalt/hectare which is greater by $43.2 \%$ than the control plot and level fanyajuu 27.82 quintal/hectare that is (50.9\%) higher than the control plot (Table 2). The average wheat yield obtained in level fanyajuu was higher than the level bund and control plot followed by the level bund. At the same time level fanyajuu treated plots had gained an increase in plant height and 1,000 seed weight of wheat which is $12 \mathrm{~cm}(14.1 \%), 9 \mathrm{gm}(27.3 \%)$ over the untreated plot, respectively.

Table 2. Wheat yield and yield parameters

\begin{tabular}{|c|c|c|c|c|c|c|c|c|}
\hline \multirow[t]{2}{*}{ Treatments } & \multicolumn{2}{|c|}{ Number of seed per spike } & \multicolumn{2}{|c|}{ Plant height in cm } & \multicolumn{2}{|c|}{$\begin{array}{l}\text { 1000seed weight } \\
\text { (gm) }\end{array}$} & \multicolumn{2}{|c|}{$\begin{array}{l}\text { Grain yield in } \\
\text { Quintal/hectare }\end{array}$} \\
\hline & Mean & Std. & Mean & Std. & Mean & Std. & Mean & Std. \\
\hline Level bund & 31.19a & $8.76^{*}$ & $95 a$ & $10^{*}$ & $40 \mathrm{a}$ & $7^{*}$ & 26.39a & $7.96^{*}$ \\
\hline Level fanyajuu & $30.81 \mathrm{a}$ & $8.38^{*}$ & $97 \mathrm{~b}$ & $12^{*}$ & $42 a$ & $9^{*}$ & $27.82 \mathrm{a}$ & $9.39^{*}$ \\
\hline Control & $22.43 b$ & - & $85 c$ & - & $33 b$ & - & 18.43 & - \\
\hline CV (\%) & \multicolumn{2}{|c|}{16.05} & \multicolumn{2}{|c|}{5.31} & \multicolumn{2}{|c|}{11.2} & \multicolumn{2}{|c|}{15.9} \\
\hline LSD (0.05) & \multicolumn{2}{|c|}{2.82} & \multicolumn{2}{|c|}{3.08} & \multicolumn{2}{|c|}{2.66} & \multicolumn{2}{|c|}{2.4} \\
\hline
\end{tabular}

$\mathrm{CV}=$ Coefficient of variance $\mathrm{LSD}=$ least significant difference means significantly different at ( $\mathrm{P} \leq 0.05$ ), (Source survey result). 
It is difficult to formulate a one-to-one, cause and effect relationship between crop yields on the one hand and soil erosion and erosion induced soil degradation on the other [25]. Under field condition, it will be difficult to relate crop yield to any individual factor which is an integrated response of many parameters. According to [26], the vast quantity of our soil washed away every year contains 92,172 and 300 tons of phosphorus, Potassium, Nitrogen, Calcium and Magnesium as computed from the average analysis of 389 samples of surface soil collected throughout the United State.

As shown in Table 3, the highest (40.05 quintal/hectare) and the lowest (14.71 quintal/hectare) grain yield of wheat was recorded on the level bund treated plot at North Ballesa-two and on control plot North Ballesa-one respectively. On considering the average of all conservation measures on all locations the highest (32.28 quintal/hectare) grain yield was obtained at North Ballesa-two and the lowest (19.68 quintal/hectare) is recorded at North Ballesa-one (Table 3). In general, all the average grain yield and agronomic characteristics displayed the lowest record in the control plot in all seven locations.

Table 3. Wheat yield on seven locations of the experimental plot

\begin{tabular}{cccccccccc}
\hline \multirow{2}{*}{ Conservation Measures } & \multicolumn{7}{c}{ Wheat grain yield quintal/hectare on seven locations } \\
\cline { 2 - 9 } & $\mathrm{R}_{1}$ & $\mathrm{R}_{2}$ & $\mathrm{R}_{3}$ & $\mathrm{R}_{4}$ & $\mathrm{R}_{5}$ & $\mathrm{R}_{6}$ & $\mathrm{R}_{7}$ & Means \\
\hline Level Bund & 19.45 & 40.05 & 24.81 & 22.1 & 24.29 & 31.01 & 23.1 & 26.4 \\
Level fanyajuu & 24.79 & 27.79 & 33.64 & 23.64 & 26.05 & 29.43 & 27.32 & 27.52 \\
Control & 14.71 & 26.99 & 20.14 & 19.43 & 15.86 & 17.07 & 17.15 & 18.76 \\
Means & 19.68 & 32.28 & 26.2 & 21.72 & 22.07 & 25.84 & 22.52 & \\
\hline
\end{tabular}

${ }^{*} \mathrm{R}_{1}$ to $\mathrm{R}_{7}=$ Locations/Replication one to seven (Source: survey result)

The 1,000-seed weight in level bund and level fanyajuu was significantly higher $(\mathrm{P} \leq 0.05)$ than the control plot. There is no significant difference between level bund and level fanyajuu treated plots. The mean 1000 -seed weight of wheat grown under level bund and level fanyajuu treated plots were $7 \mathrm{gm}$ (21.2\%) and 9 gm (27.3\%) higher respectively than the control plot. This implies that 1000-seed weight is one of the important components of wheat yield.

Among the seven locations the highest average 1,000-seed weight was recorded (42.11 gm) at North-Ballesa-three and the smallest (33.46 gm) was at Ana Ballesa-five. Statistically significant difference $(\mathrm{P} \leq 0.05)$ was also observed on 1000-seed weight (Table. 2). The lowest average 1,000 seed weight observed in Ana Ballesa-five was due to low value recorded on control plot. This implies also low level of organic matter and nutrients on the location. A statistically significant difference $(\mathrm{P} \leq 0.05)$ was also observed on the number of seeds per spike between level bund, level fanyajuu and the control plot (Table 2). The mean difference of number of seeds per spike on level bund was (8.76) and on level fanyajuu (8.38) higher than the control plot (Table 2). There was no significant difference between level bund and level fanyajuu. The average1,000 seed weight recorded on level bund and level fanyajuu was (21.75\%) and (29.03\%) greater than the control plot respectively. The mean highest number of seeds per spike among locations was 35 recorded at North-Ballesa-two and the lowest 22 at Ana-Ballesa-five. A greater degradation of physical and chemical properties on the control plot greatly affected the wheat yield and agronomic characteristics. This may be due to increased erosion and erodibility on the control plot may be because of the reduction of organic matter. Plot studies at Hilton experimental sites, [27] showed that small reduction in soil organic matter content markedly increased erodibility and erosion [28-29].

Table 4. Average wheat yield as measured on conservation structure

\begin{tabular}{cccccc}
\hline Treatments & Plant height in (cm) & $\begin{array}{c}\text { Number of seeds } \\
\text { per spike }\end{array}$ & 1000 seed weight in (gm) & Days to 50\% spiking & $\begin{array}{c}\text { Grain yield in } \\
\text { quintal/hectare }\end{array}$ \\
\hline Level bund & 95 & 31 & 39.63 & 66.6 & 26.39 \\
Level fanyajuu & 97 & 31 & 42 & 67.4 & 27.82 \\
Control & 85 & 22 & 32.55 & 70.85 & 18.43 \\
\hline
\end{tabular}

(Source: survey result)

As shown in Table 4, the average value of days to 50\% spiking for level bund was 66.6 and level fanyajuu was 67.4 whereas for control plot was 70.85 . This shows those days to $50 \%$ spiking was delayed on control plot; because of nutrient deficiency on the control plot due to erosion by water. Plants grow slowly when nitrogen is deficient; they also appear spindly, stunted and pale when compared with healthy plants. The pale green color of nitrogen-deficient plants results from a shortage of chlorophyll because chlorophyll is needed for carbohydrate production by photosynthesis, [24] 
and [30] A tentative identification of a phosphorus deficiency made on the basis of such symptoms as stunting, delayed maturity, dark green coloration, and purple spots or streaks.

Among the seven locations, the highest $(107 \mathrm{~cm})$ and the smallest plant height $(81 \mathrm{~cm})$ was observed at Ana-Ballesa-three and Amibicho-six, respectively. This is due to different physical and chemical properties of soil in the locations and lack of conservation structures on the control plot. As shown in Table 4, the smallest plant height is observed on control plot $(85 \mathrm{~cm})$. This may be due to lower content of nutrients on the control plot which is similar to study by $[31,19]$ observed a decrease in plant height with loss of nitrogen, phosphorus, and potassium and soil organic matter by erosion which is usually followed by reduction in soil $\mathrm{pH}$. Soils may be deficient in organic matter leading to shortage of nitrogen, phosphorus and potassium. These deficiencies retarded plant growth, cause poor colour and affect the quality of crop productivity.

\subsection{Correlation of Wheat Yield and Soil Conservation Structures}

Correlation analysis was used to describe the strength and direction of the linear relationship and to show the properties most affected by erosion and the quantity of the detail predominant relationship among the agronomic characteristics of the wheat crop and the soil and water conservation structures on the one hand and the soil physico-chemical proprieties and yield on the other. (Table 5 and Table 6) show the correlation between wheat yield and some of the agronomic characteristics and soil physico-chemical properties with the soil and water conservation structures. Pearson's correlation (r) ranges from -1 to 1 . This value indicates the strength of the relationship between variables. Study by scholars [32] and [33] had suggested the following guide line of interpreting Pearson's correlation (r). The negative sign according to the guide line applies only to the direction of the relationship not the strength.

As indicated in Table 5, wheat yield showed positive and significant correlation values with 1,000 seed weight on level bund $(\mathrm{r}=.577)$, level fanyajuu $\left(\mathrm{r}=.683^{*}\right)$, whereas it showed negative and small correlation with control plot $(\mathrm{r}=-.280)$. wheat yield correlated negatively on all treated and untreated plots with number of seeds per spike and showed significant and large correlation on level fanyajuu treated plot $\left(\mathrm{r}=-.925^{* *}\right)(\mathrm{P} \leq 0.01)$, whereas plant height showed positive and medium correlation on level bund $(\mathrm{r}=.419)$ and negative correlation on level fanyajuu and control plot $(r=-.464)$ and $(r=-.348)$, respectively.

Table 5. Correlation between wheat yield and different conservation structures

\begin{tabular}{cccc}
\hline Soil/crop characteristic & Level bund & Level fanyajuu & Control \\
\hline Number of seed/spike & -.466 & $-.925^{* *}$ & -.453 \\
1,000 seed weight & .577 & $.683^{*}$ & -.280 \\
Plant height & .419 & -.464 & -.348 \\
\hline
\end{tabular}

${ }_{\text {N.B }}^{* *}$ Correlation is significant at $(\mathrm{P} \leq 0.01)$. ${ }^{*}$ Correlation is significant at $(\mathrm{P} \leq 0.05)$. (Source: survey result)

Table 6. Correlation between wheat yield, and soil chemical properties

\begin{tabular}{cccc}
\hline Soil/crop characteristic & Level bund & Level fanyajuu & Control \\
\hline Total nitrogen & -.501 & -.662 & .403 \\
Organic matter & .305 & .596 & .159 \\
Organic carbon & .433 & .594 & .152 \\
CEC & -.568 & -.282 & -.213 \\
\hline
\end{tabular}

(Source: survey result)

Organic carbon and organic matter showed a medium relationship on level bund whereas, total nitrogen and cation exchange capacity showed large relationship. On the other hand total nitrogen, organic carbon, organic matter and cation exchange capacity showed large relationship on level fanyajuu whereas the relationship on untreated plot was small and insignificant. Organic matter loss not only results in reduced water holding capacity and soil degradation but also the loss of plant nutrients which are used to increase yield. This was confirmed by [34] and [6], the major problem to the farm associated with soil erosion come from loss of nutrients and reduced water holding capacity, accounting 50 to $70 \%$ of productivity loss. [35] also showed that the effects of erosion from slight to severe on organic matter soil phosphorus level, and plant available water reduces their content from 3\% to 1.9\%, $31 \mathrm{~kg} / \mathrm{acre}$ to $20 \mathrm{~kg} / \mathrm{acre}$ and $7.4 \%$ to $3.6 \%$, respectively which in-turn affects productivity of the land.

Among the soil physical properties clay, sand and total porosity have a large correlation because they have the value greater than 0.5 and -0.5 . This was due to soil erosion which changes the texture of the plough layer by washing away the organic fine textured and fertile soil and exposing the sand particles in the lower horizons. Clay has got a negative 
and significant correlation with wheat yield $\left(\mathrm{r}=-.728^{*}\right.$ and $\left.\mathrm{r}=-.748^{*}\right)$ with level bund and level fanyajuu whereas it has a positive and insignificant correlation with control plot $(\mathrm{r}=.182)$ which is showing a small correlation (Table 7). Sand has a positive and significant correlation with level bund $\left(\mathrm{r}=.723^{*}\right)$ and a positive correlation $(\mathrm{r}=.546)$ with level fanyajuu, negative and insignificant correlation with control plot. A small and insignificant correlation on the control plot was due to erosion problem which has taken the finer topsoil from untreated plot and left behind the coarser soil that reduces the organic matter content and plant nutrient casing yield reduction on the control plot.

Table 7. Correlation between wheat yield and soil physical characteristics

\begin{tabular}{cccc}
\hline Soil/crop characteristic & Level bund & Level fanyajuu & Control \\
\hline Bulk density & -.482 & -.449 & -.397 \\
Total porosity & .575 & $-.806^{*}$ & .389 \\
water holding capacity & $.715^{*}$ & .486 & .340 \\
Clay & $-.728^{*}$ & $-.748^{*}$ & .182 \\
Sand & $.723^{*}$ & .546 & -.327 \\
\hline
\end{tabular}

N.B. ${ }^{*}$ Correlation is significant at ( $\left.\mathrm{p} \leq 0.05\right)$ (Source: survey result)

Total porosity has got a positive and large correlation with wheat yield on level bund (Table 7). It has negative, significant and large correlation on level fanyajuu, whereas, it has got a positive and medium correlation on the control plot. The other texture related soil physical property such as bulk density has got a negative and large correlation on level bund and level fanyajuu. It has also got a negative and medium correlation with control plot. Available water holding capacity showed a positive; large and medium correlation with wheat yield on level bund and level fanyajuu respectively and a positive and medium correlation on the control plot. Available water showed significant correlation with level bund. This was due to clay content and structural arrangement of the soil. It varies also with soil treatment because the size and distribution of pores in the top soil reflects surface exposure, normal seasonal wetting and drying and management. [8] and [36] studying the water content of soil samples found that the available soil water of well-structured soil was one third twice as large as that in poorly structured or degraded soil. [29] and [37] confirmed that significant differences in porosity and water holding capacity occurs only when exposed soil material are intensively cultivated and the soil are structurally degraded.

\section{Conclusion and Recommendation}

\subsection{Conclusion}

The use of crop management practices like mulching, and leaving crop residues on the field to control soil erosion was difficult in the study area, because of the absence of crop cover when it is most needed, as they are mainly used for animal feed. Consequently mechanical conservation measures are of great importance. Much of the present efforts of conservation are based on the building of cut-offs and in construction of level bunds and level fanyajuu. Soil conservation treated plots in the area showed significant difference $(\mathrm{P} \leq 0.05)$ on wheat plant height, number of seed per spike, days to $50 \%$ spiking and grain yield. The relative average mean of $55 \%$ was recorded on the level fanyajuu and $45 \%$ increment was recorded on level bund.

Level bund and level fanyajuu which are widely used in the area showed an increment in crop yield. Soil erosion affects crop production primarily because it affects (a) soil nutrients (b) the soil water holding capacity (c) bulk density (d) soil tiles (e) infiltration of the soil and others. These facts were shown on the study area on the control plots. The overall results of this study indicated that soil and water conservation structures increased crop yield which may be because of improved soil properties.

\subsection{Recommendations}

Soil and water conservation measures should have to be exercised on cultivated land where there is soil erosion problem. Raising yield per hectare and improving the quantity of product will increasingly difficult without a steady use of soil and water conservation technologies by the farmers. Hence the government should encourage the respective offices to extend soil and water conservation technologies to be used by all farmers of the area in order to achieve the goal intended in agricultural crops.

A greater work should have to be done to increase farmer's source of information and technical assistance that will help those increases their awareness and recognizes soil erosion as a problem on their own farm. The "mass media", especially farm magazines, should be used in greater amounts for the dissemination of conservation information in the farmers training center, day of farmer's demonstration and by written leaflets. The role soil and water conservation 
should be clarified, as common goals among the stakeholders should be firmly established, and a teamwork approach of public and private organizations at the local level should be emphasized. Obstacles to soil and water conservation should be identified at the local level and dealt with as part of the program implementation process.

\section{Acknowledgements}

We would like to forward our gratitude to Wachemo University for funding and to all who has made of any enhancement for the success of this study.

\section{References}

[1] Bogale, M., Regassa, A., \& Tilahun, A. (2020). Inter-structural Space Effect of Fanyajuu and Soil Bund Soil and Water Conservation Structures on Selected Soil Properties: In the Case of Habru District, North Ethiopia.

[2] Tilahun, A., Belay, F. (2019). Conservation and production impacts of soil and water conservation practices under different socio-economic and biophysical setting: a review. Journal of Degraded and Mining Lands Management, 6(2), p. 1653.

[3] Hailu, L. (2019). Effects of Soil and Water Conservation on Selected Soil Physicochemical Properties and Its Implication on Soil Productivity in Ethiopia. A Review.

[4] Mushir, A., \& Kedru, S. (2012). Soil and water conservation management through indigenous and traditional practices in Ethiopia: A case study. Ethiopian Journal of Environmental Studies and Management, 5(4), pp. 343-355.

[5] Wolka, K., Moges, A., and Yimer, F. (2013). Farmers' perception of the effects of soil and water conservation structures on crop production: The case of Bokole watershed, Southern Ethiopia. African journal of environmental science and technology, 7(11), pp. 990-1000.

[6] Adimassu, Z., Langan, S., Johnston, R., Mekuria, W., \& Amede, T. (2017). Impacts of soil and water conservation practices on crop yield, run-off, soil loss and nutrient loss in Ethiopia: review and synthesis. Environmental management, 59(1), pp. 87-101.

[7] Subhatu, A., Lemann, T., Hurni, K., Portner, B., Kassawmar, T., Zeleke, G., \& Hurni, H. (2017). Deposition of eroded soil on terraced croplands in Minchet catchment, Ethiopian Highlands. International soil and water conservation research, 5(3), pp. 212-220.

[8] Lal, R. (2020). Soil organic matter content and crop yield. Journal of Soil and Water Conservation, 75(2), pp. 27A-32A.

[9] Melaku, N. D., Renschler, C. S., Flagler, J., Bayu, W., \& Klik, A. (2018). Integrated impact assessment of soil and water conservation structures on runoff and sediment yield through measurements and modeling in the Northern Ethiopian highlands. Catena, 169 , pp. 140-150.

[10] Lakew, W. J. (2018). Effect of soil and water conservation measures on hydrological processes and sediment yield in the highlands of North-Western Ethiopia (Doctoral dissertation, Wageningen University).

[11] Guadie, M., Molla, E., Mekonnen, M., \& Cerdà, A. (2020). Effects of Soil Bund and Stone-Faced Soil Bund on Soil Physicochemical Properties and Crop Yield Under Rain-Fed Conditions of Northwest Ethiopia. Land, 9(1), p. 13.

[12] DAaNRD (Department of Agricultural and Natural Resources Development) (2017). Five Years Development Report.

[13] Dunn, B. W., Dunn, T. S., \& Orchard, B. A. (2016). Nitrogen rate and timing effects on growth and yield of drill-sown rice. Crop and pasture Science, 67(11), pp. 1149-1157.

[14] Singh, G., Singh, B., \& Rathore, T. S. (2013). Effects of agroforestry land use on microclimate modification and productivity in dry areas. Indian Journal of Agroforestry, 15(2), pp. 68-78.

[15] Creswell, J. W., \& Clark, V. P. (2011). Designing and conducting mixed methods research. Retrieved on July, 25 , p. 2014.

[16] Creswell, J. W. (2009). Editorial: Mapping the field of mixed methods research. Journal of Mixed Methods Research, 3(2), pp. 95-108.

[17] Van Jaarsveld, E. (2013). Waterwise gardening in South Africa and Namibia. Penguin Random House South Africa.

[18] Munkholm, L. J., Heck, R. J., \& Deen, B. (2013). Long-term rotation and tillage effects on soil structure and crop yield. Soil and Tillage Research, 127, pp. 85-91.

[19] Adgo, E., Teshome, A., \& Mati, B. (2013). Impacts of long-term soil and water conservation on agricultural productivity: The case of Anjenie watershed, Ethiopia. Agricultural Water Management, 117, pp. 55-61.

[20] Lampurlanés, J., Plaza-Bonilla, D., Álvaro-Fuentes, J., \& Cantero-Martínez, C. (2016). Long-term analysis of soil water conservation and crop yield under different tillage systems in Mediterranean rainfed conditions. Field Crops Research, 189, pp. 59-67.

[21] Bazongo, P., Traore, K., Traore, O., Yelemou, B., Sanon, K. B., Kabore, S., Hien, V., \& Nacro, B. H. (2015). Influence of Jatropha hedges on the yield of a sorghum crop (Sorghum vulgare) in the western region of Burkina Faso: case of Torokoro locality. International Journal of Biological and Chemical Sciences, 9(6), pp. 2595-2607.

[22] Assefa, T., Jha, M., Reyes, M., Worqlul, A. W., Doro, L., \& Tilahun, S. (2020). Conservation agriculture with drip irrigation: Effects on soil quality and crop yield in sub-Saharan Africa. Journal of Soil and Water Conservation, 75(2), pp. 209-217. 
[23] Amare, T., Terefe, A., Selassie, Y. G., Yitaferu, B., Wolfgramm, B., \& Hurni, H. (2013). Soil properties and crop yields along the terraces and toposequece of Anjeni Watershed, Central Highlands of Ethiopia. Journal of Agricultural Science, 5(2), p. 134.

[24] Taye, G., Poesen, J., Wesemael, B. V., Vanmaercke, M., Teka, D., Deckers, J., Goosse, T., Maetens, W., Nyssen, J., Hallet, V., \& Haregeweyn, N. (2013). Effects of land use, slope gradient, and soil and water conservation structures on runoff and soil loss in semi-arid Northern Ethiopia. Physical Geography, 34(3), pp. 236-259.

[25] Teshome, A., Rolker, D., \& de Graaff, J. (2013). Financial viability of soil and water conservation technologies in northwestern Ethiopian highlands. Applied Geography, 37, pp. 139-149.

[26] Sörlin, S., \& Wormbs, N. (2018). Environing technologies: A theory of making environment. History and Technology, 34(2), pp. 101-125.

[27] Ball, B. C., \& Munkholm, L. J. (eds.) (2015). Visual Soil Evaluation: Realizing potential crop production with minimum environmental impact. CABI.

[28] Donjadee, S., \& Tingsanchali, T. (2016). Soil and water conservation on steep slopes by mulching using rice straw and vetiver grass clippings. Agriculture and Natural Resources, 50(1), pp. 75-79.

[29] Lakew, W., Baartman, J., Fleskens, L., Selassie, Y., \& Ritsema, C. (2019). Measuring and modelling the impacts of soil and water conservation measures on soil erosion and sediment yield in North-Western Ethiopian highlands. Authorea Preprints.

[30] Dimtsu, G. Y., Kifle, M., \& Darcha, G. (2018). Effect of soil and water conservation on rehabilitation of degraded lands and crop productivity in Maego watershed, North Ethiopia. Journal of Degraded and Mining Lands Management, 5(3), p. 1191.

[31] Sharma, K. L., Reddy, K. S., Chary, G. R., Indoria, A. K., Srinivas, K., Chandrika, D. S., Lal, M., Prabhakar, M., Prathiba, G., Thakur, P., \& Vasavi, M. (2018). Effect of surface residue management under minimum tillage on crop yield and soil quality indices after 6 years in sorghum (Sorghum bicolor (L.) Moench)-cowpea (Vignaunguiculata) system in rainfedAlfisols. Indian Journal of Dryland Agricultural Research and Development, 33(1), pp. 64-74.

[32] Nyangena, W., \& Köhlin, G. (2009). Estimating returns to soil and water conservation investments-an application to crop yield in Kenya.

[33] Demelash, M., \& Stahr, K. (2010). Assessment of integrated soil and water conservation measures on key soil properties in South Gonder, North-Western Highlands of Ethiopia. Journal of Soil Science and Environmental Management, 1(7), pp. 164-176.

[34] Yaekob, T., Tamene, L., Gebrehiwot, S. G., Demissie, S. S., Adimassu, Z., Woldearegay, K., Mekonnen, K., Amede, T., Abera, W., Recha, J. W., \& Solomon, D. (2020). Assessing the impacts of different land uses and soil and water conservation interventions on runoff and sediment yield at different scales in the central highlands of Ethiopia. Renewable Agriculture and Food Systems, pp. 1-15.

[35] Zhao, J., Yang, Z., \& Govers, G. (2019). Soil and water conservation measures reduce soil and water losses in China but not down to background levels: Evidence from erosion plot data. Geoderma, 337, pp. 729-741.

[36] Rashid, M., Alvi, S., Kausar, R., \& Akram, M. I. (2016). The effectiveness of soil and water conservation terrace structures for improvement of crops and soil productivity in rainfed terraced system. Pakistan Journal of Agricultural Sciences, 53(1).

[37] Kumar, S., Singh, D. R., Singh, A., Singh, N. P., \& Jha, G. K. (2020). Does Adoption of Soil and Water Conservation Practice Enhance Productivity and Reduce Risk Exposure? Empirical Evidence from Semi-Arid Tropics (SAT), India. Sustainability, 12(17), p. 6965. 